\title{
A BREEDING BIRD SURVEY ON UNCULTIVATED GRASSLAND AT REGINA
}

\author{
by Hugh and Joyce Smith, 1357 Minto Street, Regina
}

During the summer of 1965 (May to August) we conducted a breedingbird survey on a fenced prairie pasture of approximately 40 acres situated on the western outskirts of the city of Regina (NW $\frac{1}{4}$ 27-17-20w2). The area selected was not known to have been cultivated and for this season was being used for grazing eight to 12 horses. After obtaining the permission of the owner we plotted the pasture out in a 100 foot grid. All intersections were staked and marked. All of the nests located were paced off and plotted on a graph map.

Miss Gwen Jones, a biology student at the University of Saskatchewan, Regina Campus, identified the flora in the study area, compiling a list of 48 species. The most conspicuous vegetation was western snowberry, Symphoricarpos occidentalis $\mathrm{Hook}$, in a number of concentrated patches, and pasture sage, Artemisia frigida Willd., which was evenly distributed throughout the area. Also common in their season were crocus anemone, Anemone patens L.; scarlet mallow, Spheralcia coccinea (Nutt.) Piper; and wild flax, Linum lewisii Pursh. Other prominent species included crested wheat grass, Agropyron crestatum (L.) Gaertn.; foxtail barley, Hordeum jubatum L.; low prairie rose, Rosa arkansana Porter; slender wheat grass, A. trachycaulum (Link) Malte; and speargrass, Stipa comata Trin. and Rupr.

The plot was bounded on the immediate north, south, and east by similar habitat. The outer boundaries included a railroad line and a grain field on the north, a grid road and Wascana Creek (elevation 1,850 feet) on the south, and an unworked but previously cultivated field grown to weeds on the east. A rectangular plot extending from the southwest corner of the study area contained habitat similar to that of the study area. A cultivated plot of oats formed the north- west boundary and to the west of this was a farmhouse and buildings, including a dugout.

The study area was flat prairie of elevation 1,900 feet. It was crossed by a single row of deep ruts from an old trail.

Reports obtained from the Regina Airport Weather Office gave the following coverage over the study period. Normals are based on a 30 -year period from 1931 to 1960 . Total precipitation of 3.74 inches (normal 1.59 inches), and a mean wind velocity of $18.9 \mathrm{mph}$ (normal $14.0 \mathrm{mph}$ ) gave Regina its wettest May in 33 years and the windiest May on record. A high of $78^{\circ}$ on the 12th and 16th and a low of $26^{\circ}$ on the 3rd made the mean monthly temperature $49.4^{\circ} \mathrm{F}$ (normal $52.2^{\circ}$ ). Heavy snow May 25 and 26 left 5.1 inches, the total for the month. This compares with a normal total of 0.9 inches. Total precipitation in June was 4.96 inches (normal 3.28 inches). The mean monthly temperature was $60.5^{\circ} \mathrm{F}$ (normal $59.5^{\circ} \mathrm{F}$ ) with a high of $87^{\circ}$ on the 11 th and a low of $37^{\circ}$ on the 8th. 1965 had the wettest combined May-June in 59 years. In July a high of $91^{\circ}$ on the $28 \mathrm{th}$ and a low of $47^{\circ}$ on the 9 th and 25 th gave a mean monthly temperature of $66.1^{\circ} \mathrm{F}$ (normal $66.7^{\circ} \mathrm{F}$ ). Total precipitation for July was 1.69 inches (normal 2.16 inches).

Daily visits were made to the study area from May 1 to June 11 and from June 25 to August 15, 1965. All visits were made between 10:00 a.m. and 8:00 p.m., each visit lasting from one to three hours.

A count taken at noon on July 9 recorded: Chestnut-collared Longspur males 33, females 16; Lark Bunting males 24, females 3; Gray Partridge 2 ; Brown-headed Cowbird 9; Claycolored Sparrow 2. On this day (July 9) we had the following numbers of active nests under observation: 
Chestnut-collared Longspur 9, and Lark Bunting 2. The greatest number of active nests under observation for each nesting species on a given day was: Chestnut-collared Longspur 12 on July 11, 12, and 13; Lark Bunting 4 on July 13; Western Meadowlark 2 from June 6 to June 8; Clay-colored Sparrow 3 on July 29.

Visitors to the study area included one or usually more Killdeer, Gray Partridge, Sparrow Hawk, Brewer's Blackbird, Common Crow, Franklin's Gull, Ring-billed Gull, American Avocet, Red-winged Blackbird, Eastern Kingbird, Western Kingbird, Mourning Dove, Vesper Sparrow, House Sparrow, Robin, Rock Dove, Barn Swallow, and a buteo hawk which was seen alone on several occasions. Other fauna seen on the study area were White-tailed Jack Rabbit, various mice, and Richardson's Ground Squirrel.

The most abundant nesting species on this pasture was the Chestnutcollared Longspur (Calcarius ornatus) for which 38 nests were found. These nests ranged in diameter from 2 to 3 inches, and in depth from $1 \frac{1}{2}$ to $21 / 2$ inches. One nest site consisted of sparse grass 4 inches deep, bared to form an open patch of earth $2 \frac{1 / 2}{2}$ inches in diameter. There was no nest structure and the nest was unsuccessful. All of the remaining 37 nests were well concealed in grass, rose, sage or snowberry, ranging in depth from 4 to 10 inches. The first male was seen on the study area on April 24, and the first nest was found containing one egg on May 13. The last nest was vacated August 7 and adult longspurs were last seen on the study area on August 15.

A total of 141 eggs were laid in the 38 nests we found. Eleven nests were unobserved for a two-week period and their nesting success was not determined. Of the remaining 27 nests only nine successfully fledged young (36 eggs laid, 32 eggs hatched, 23 young fledged). One unsuccessful longspur nest was parasitized with two cowbird eggs. On another occasion two Chestnut-collared Longspur adults were observed feeding a young cowbird fledgling. No nest was found for this pair of longspurs.

The second most abundant nesting species on this pasture was the Lark Bunting (Calamospiza melanocorys) for which seven nests were found, ranging in diameter from $23 / 4$ to 4 inches, and in depth from $13 / 4$ to 2 inches. The nests were on the ground located in the deeper vegetation ( 7 to 24 inches deep) and usually in western snowberry. Although Lark Bunting's were first noted on the pasture on May 19, it was not until July 1 that the first nest was found. In the seven nests there were $34 \mathrm{eggs}$ of which 16 hatched and 11 young were known to have fledged.

During this study we found two Lark Bunting nests that had been parasitized by the Brown-headed Cowbird. One nest contained three cowbird eggs along with four Lark Bunting eggs. The other nest contained two cowbird eggs and four Lark Bunting eggs. Both of these nests were unsuccessful, having been destroyed by an unknown predator. The Lark Bunting is not included in the list given by C. Stuart Houston of Saskatchewan species known to be parasitized by the Brown-headed Cowbird (see Houston's review of Host relations of the parasitic cowbirds in Blue Jay, 24:44). We have since learned, however, that R. W. Nero (pers. comm., 1966) found a Lark Bunting nest with three eggs on July 9,1964 in this same study area - on July 10 this nest held only two eggs; on July 12, two Lark Bunting eggs plus one cowbird egg, but these eggs were cold and the nest appeared deserted (at 9:00 a.m.).

Nesting observations were made in this study area for four other species of birds: Western Meadowlark (Sturnella neglecta), Horned Lark (Eremophila alpestris), Mallard (Anas platyrhynchos) and Claycolored Sparrow (Spizella pallida). One Western Meadowlark nest was found in the study area and two more just beyond. All these nests were built on the ground, concealed in 


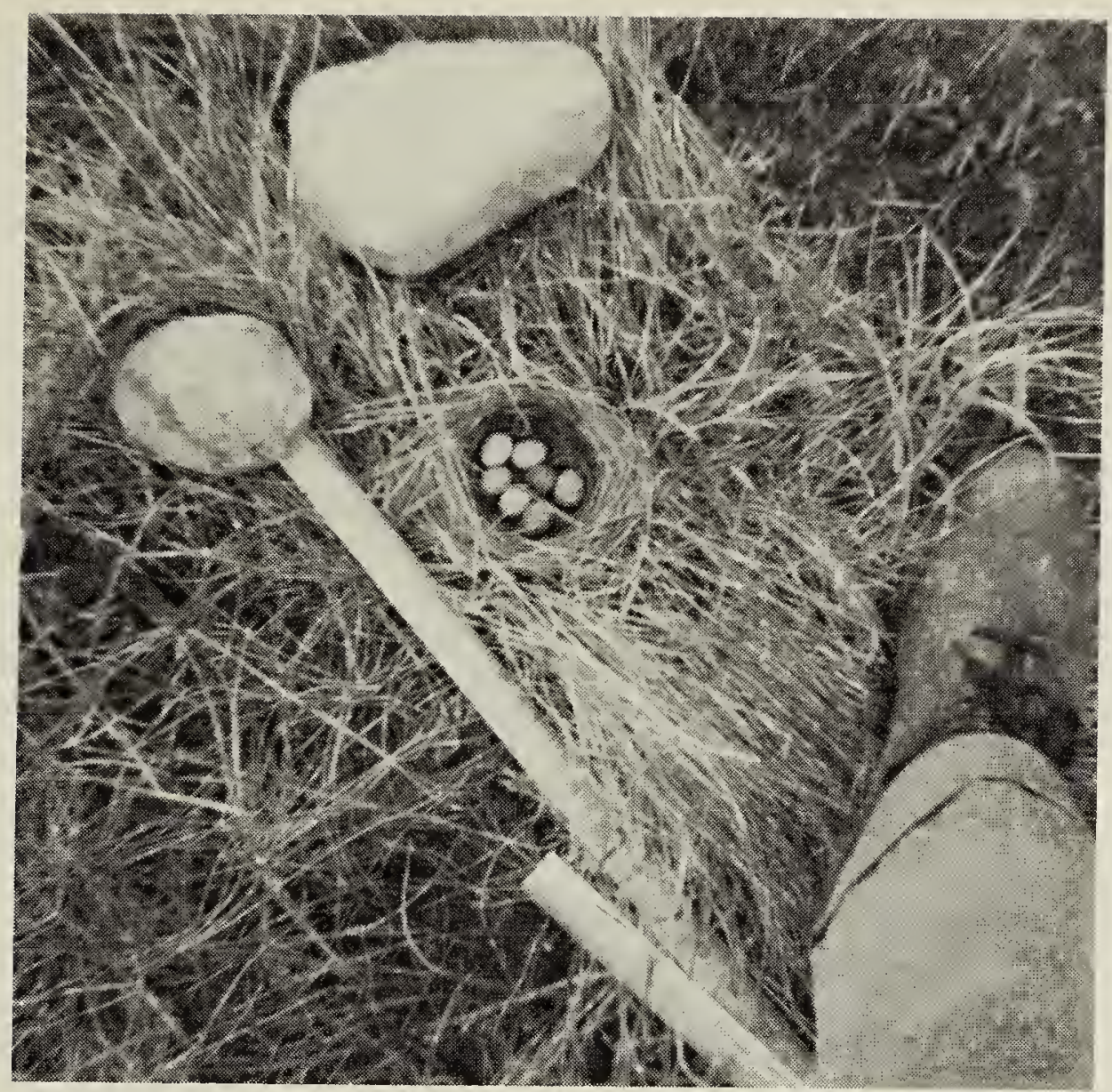

Lark Bunting nest in Regina, 1965. The 7 eggs include 4 Lark Bunting eggs and 3 Brown-headed Cowbird eggs.

grasses 9 to 14 inches deep. A total of 12 eggs were laid of which six eggs hatched and three young fledged. Two of the nests were complete failures and the three successful fledglings were all from one nest in which only three eggs had been laid. A single Horned Lark nest was found, similar in construction and habitat to the Chestnut-collared Longspur's. From this nest were fledged two young from three eggs hatched of three eggs laid. These young were fledged on May 23 and no further Horned Lark nests were found on the study area that season. Three Clay-colored Sparrow nests, suspended 10 to 18 inches above the ground, were all found in snowberry 18 to 24 inches high. There were eight eggs laid, five young hatched and fledged. One nest of three eggs was a complete failure. One Mallard egg was found in snowberry 20 inches deep. No nest structure was apparent, and the egg was abandoned after the female was flushed on two successive days.

On two occasions a Richardson's Ground Squirrel was seen being chased by a male Chestnut-collared Longspur from the bird's nest site. The large number of ground squirrels seen on the study area would indicate that they were serious predators. We considered the presence of the horses grazing on the pasture to be a possible source of a small percentage of nest failure. One Chestnutcollared Longspur and one Lark Bunting nest were each thought to have been trampled, and one Clay-colored Sparrow nest was pushed over, spilling the eggs.

A unique aspect of this study area is its situation within the city limits. The pasture was being surveyed by a survey crew most of the summer. Owing to urban expansion and the present proximity to residential areas it is not likely the area will remain as grassland.

Financial support for this study was provided by the University of Saskatchewan Regina Campus through a grant to Dr. Robert W. Nero. We wish to thank Dr. Nero for encouraging us to undertake this survey. 